研究

\title{
MIM プロセスを応用した生体活性チタンの作成
}

\author{
北島 明子出 1 ，清水 透山1，伊藤 敦夫山2 \\ 中1 産業技術絵合研究所機械システム研究部門，テ305-8564つくば市並木1-2. \\ 中2 産業技術総合研究所 人間福祉医工学研究部門， テ305-8562 つくば市東1-1-1 中央第 4.
}

\section{Fabrication of Bioactive Titanium Parts by MIM Techniques Using Surface Treatment}

\author{
Akiko Kitajima ${ }^{\text {1 }}$, Toru Shimizu ${ }^{\text {t }}$ and Atsuo Ito 2 \\ «1 National Institute of Advanced Industrial Science and Technology, 1-2 Namiki, Tsukuba 305-8564. \\ ${ }^{2}$ National Institute of Advanced Industrial Science and Technology, Central 4, 1-1-1 Higashi, Tsukuba 305-8562.
}

Received December 13, 2002

\begin{abstract}
SYNOPSIS
Though $\mathrm{Ti}$ and $\mathrm{Ti}$ alloy with thermal sprayed apatite coatings have been applied to artificial joints and dental implants, the coatings are hard to combine directly with the substrates. In this study, a new rapid and easy surface treatment, by which the reactants can combine to the substrates directly, has been invented. It is a high apatite forming method. Among the substances generated by the treatment, one shows strong alkali, and others are considered to act as kernels during the bone-like apatite layer growth process. From these kernels, effective bone-like apatite layer can form on the surface of the substrates in a simulated body fluid (SBF).
\end{abstract}

KEY WORDS

Surface treatment, bone-like apatite layer, artificial joint, dental tools, SBF

\section{1 緒 論}

加齢による骨折や骨の縮腿, 事故などによる欠損医療には 欠損部が小さい場合，患者自身の自家骨や親族や他人からの 同種骨が移植される.しかし，傊部が大きく自家骨で補え ない場合や同種骨が得られない場合には人工骨が用いられて いる.高龄化社会を迎える上で人工骨は大いなる需要が見込 まれている. 人工骨，人工関節，人工歯根として生体適合性 の高い純チタン及びチタン合金 ${ }^{1-19)}$ の鋳物が用いられている が,これらは難加工性材料であり，鋳造後の仕上げ工程が必 須である. 射出成形法は, 近年プラスチックの成形加工法と して汎用に用いられているが, 金属やセラミックスなどの成 形体をネットシェイブで量産する射出成型法 (MIM, CIM) ${ }^{20)}$, 特に精密機械部品の生産方法として有力である.しかしなが ら MIM法は，生体材料分野において，小型で形状が同一な人 工歯根などの製造技術として可能性を有しているが，加熱脱 脂法を経て作成した烧結体の引張強度不足問題があり実現 に至っていない。我々は, 超臨界脱脂を用いたMIM 法により 優れた機械的特性を持つ純チタン母材を開発する事に成功し $\star^{21)}$.

人工骨は，その表面に生体材料であるヒドロシキアパタイ
ト $\left(\mathrm{HAP}, \mathrm{C}_{10}\left(\mathrm{PO}_{4}\right)_{6}(\mathrm{OH})_{2}\right)$ の皮膜をコーティングし，体内で HAPから疑似骨を成長させて骨と結合する能力(生体活性)を 付与されている. 通常, HAPのコーティングには, プラズマ 溶射法 ${ }^{22-29}$ が用いられている. プラズマ溶射法では, HAPが 金属と化学結合していないため接着力が弱くHAPの剥離の問 題が生じている．小久保らは ${ }^{30-43)}, \mathrm{HAP}$ の剥離の問題を克服 するため, 水酸化ナトリウム水溶液で处理し，その後 $600^{\circ} \mathrm{C}$ で加熱処理することによりインプラント表面にアモルファス のチタン酸ナトリウムを生成させ, チタン金属に優れた機械 的物性と高い生体活性を併せ持つ人工骨用チタン及びその合 金を調整する表面処理の条件を開発した。本研究は，金属表 面と HAP 粉末に回転工具 (HAP の焼結体を取り付けた) を用 いて数分間擦り付けることにより金属表面に生体活性を付与 する小久保らより簡便，迅速な方法を提案するものである。 また，その表面処理した純チタンを生体疑似液(SBF) に侵漬 することにより金属の表面から疑似骨を生成させた骨類似ア パタイト首を確認することができた。

以上のことにより, 超臨界脱脂を用いたMIM法により優れ た機械的特性を持つ純チタン母材に高い生体活性を付与した 人工骨用チタンを開発した. 


\section{2 実験方法}

\section{1 純チタン試験片の作成}

純チタン粉TILOP-45 (住友チタニウム侏製)を平均粒径 $12.7 \mu \mathrm{m}$ に調整し，バインダ(Binder) 組成 (パラフィンワックス:ミリ スチン酸:ポリエチレン $=75: 5: 20$ (重量比) $)^{44)}$ のBinderを体 積比 TILOP-45: Binder $=60: 40$ で混練, 身出成形 (引張試験片 形状), 脱脂, 焼結した. 脱脂は, 液化二酸化炭素を液体ク口 マトグラフ用ポンプで20 MPaに昇圧し超臨界状態にした二酸 化炭素を耐圧セルに満たし $55^{\circ} \mathrm{C}, 9 \mathrm{ks}$ 保持して行った.これら の脱脂体を真空雾囲気中 $1050^{\circ} \mathrm{C}, 14.4 \mathrm{ks}$ 保持して焼結を行っ た.

\section{2 表面活性化処理}

MIM プロセスを経て作成した試験片と HAP 粉をメ力ノケ ミカル反応させるために, HAPの焼結体を回転軸に取り付け Fig.1に示すように加重 $50 \mathrm{gf} \sim 1000 \mathrm{gf}$, 回転数 $1000 \mathrm{rpm} \sim 10000$ $\mathrm{rpm}$, 加工時間 $30 \mathrm{~s} \sim 180 \mathrm{~s}$ の実験条件でチタン表面に加工を 行った. 表面処理を行った試験片に蒸留水を一滴垂らし $\mathrm{pH}$ 万能試験紙により $\mathrm{pH}$ を測定した。表面処理を行った試験片 は, $\mathrm{X}$ 線回析 $(\mathrm{XRD})$ の測定, 走查型電子顕微鏡 (SEM)による 観察, エネルギー分散型X線分析(EDX)の定性分析, 元素マッ ピング等を行った。

\section{3 過飽和リン酸カルシウム溶液処理}

\subsubsection{SBF}

ヒトの血しょうは,Table 1右欄に示す無機イオンからなる。 そこで,これに近い無機イオン濃度を有する水溶液を調整し， 疑似体液と呼ぶ.この疑似体液は，生体活性セラミックスや 金属の生体内での表面構造変化を体外で比較的正確に再現し

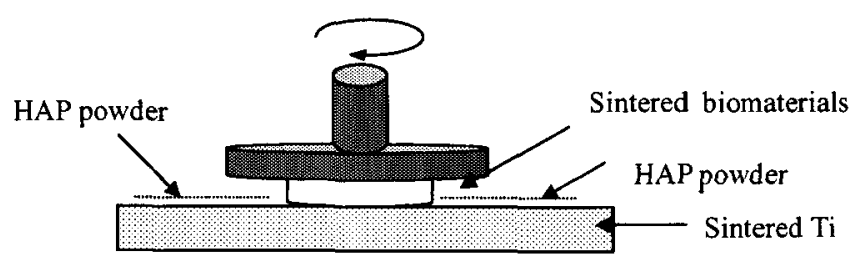

Fig.1 Schematic drawing or a tool.

Table 1 Concentration of Inorganic ion in SBF and human blood plasma (mM).

\begin{tabular}{|c|c|c|}
\hline Ion & SBF & $\begin{array}{c}\text { Human blood } \\
\text { plasma }\end{array}$ \\
\hline $\mathrm{Na}^{+}$ & 142.0 & 142.0 \\
\hline $\mathrm{K}^{+}$ & 5.0 & 5.0 \\
\hline $\mathrm{Mg}^{2+}$ & 1.5 & 1.5 \\
\hline $\mathrm{Ca}^{2+}$ & 2.5 & 2.5 \\
\hline $\mathrm{Cl}^{-}$ & 148.8 & 103.0 \\
\hline $\mathrm{HCO}^{3-}$ & 4.2 & 27.0 \\
\hline $\mathrm{HPO}_{4}{ }^{2-}$ & 1.0 & 1.0 \\
\hline $\mathrm{SO}_{4}{ }^{2}$ & 0.5 & 0.5 \\
\hline
\end{tabular}

うることが確かめられている。

\subsubsection{SBF の調整 ${ }^{45}$}

蒸留水, $\mathrm{NaCl}, \mathrm{NaHCO}_{3}, \mathrm{KCl}, \mathrm{K}_{2} \mathrm{HPO}_{4} \cdot 3 \mathrm{H}_{2} \mathrm{O}, \mathrm{MgCl}_{2} 6 \mathrm{H}_{2} \mathrm{O}$, $\mathrm{CaCl}_{2}, \mathrm{Na}_{2} \mathrm{SO}_{4}$ の各試薬, $\mathrm{pH}$ 調整用のトリスヒドロキシメチル アミノメタン $\left(\left(\mathrm{CH}_{2} \mathrm{OH}\right)_{3} \mathrm{CNH}_{2}\right)$ 緩衝凨及び $1 \mathrm{M}$ の塩酸 $(\mathrm{HCl})$ を 用意した. $1000 \mathrm{ml}$ のビーカーに $700 \mathrm{ml}$ の蒸留水を入れ，擋挥 子を入れた.これをマグネチックスターラー上に置いた恒温 槽に入れ, 蒸留水を $36.5^{\circ} \mathrm{C}$ に保つ. ビ一カーには, 時計皿で ふたをした.この蒸留水に上記の試薬をTable 2に示す順に溶 液に溶解させた。

$\mathrm{pH}$ メーターを正確に校正し，電極を十分に洗浄し，洗液を 上記の加え，その $\mathrm{pH}$ を測定した.この液に $1 \mathrm{M}-\mathrm{HCl}$ をスポイ ドで徐々に滴下し，その $\mathrm{pH} 7.4$ に調節した. $\mathrm{pH}$ メーターの 電極を液から取り出し，蒸留水で洗浄し，その洗液を上記の 液に加え $1000 \mathrm{ml}$ のメスフラスコに移し,もとのビーカーを蒸 留水で十分に洗浄し，洗液をメスフラスコ内の液に加え，液 面を $1000 \mathrm{ml}$ の標線に正確に合わせる.メスフラスコを振り， 液を十分に混合し，これをSBFとした。

\subsubsection{SBFへの浸漬と生成した疑似骨の観察}

疑似体液をスチロール棒瓶 $(100 \mathrm{ml})$ に分取し, 表面処理を施

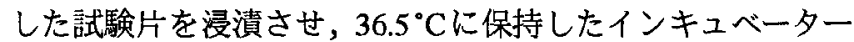
に7日間保存後, 試験片を取り出し, 蒸留水, エチルアルコー ルで洗浄, 乾燥後, XRDの測定, SEMの観察, EDXの定性分 析を行った。

\section{3 実験結果と考察}

生体活性を付与する母材の機械的特性をFig.2, 引張試験後 の破断面の SEM 像を Fig.3に示す.バルク材に比べ遜色のな い機械的特性を有し，その破断面も延性破壊されたことが理 解できる，相対密度 $98 \%$, 引張強度 $750 \mathrm{MPa}$ を越える純チ夕 ン母材に加重 $50 \mathrm{gf} \sim 1000 \mathrm{gf}$, 回転数 $1000 \mathrm{rpm} \sim 10000 \mathrm{rpm}$, 加 工時間 30s〜180sでチタン表面に生体活性を付与する加工が できた. 純チタン試験片と HAP 粉を回転工具(HAP 燒結体を 取り付けた)によって擦り付けることでメカノケミカル反応が

Table 2 The reagents are dissolved in order $(\mathrm{pH} 7.40,1 \mathrm{~L})$.

\begin{tabular}{|c|c|c|}
\hline order & reagents & $\begin{array}{c}\text { Weighed } \\
\text { amounts }\end{array}$ \\
\hline 1 & $\mathrm{NaCl}$ & $7.996 \mathrm{~g}$ \\
\hline 2 & $\mathrm{NaHCO}^{3-}$ & $0.350 \mathrm{~g}$ \\
\hline 3 & $\mathrm{KCl}$ & $0.224 \mathrm{~g}$ \\
\hline 4 & $\mathrm{~K}_{2} \mathrm{HPO}_{4} 2^{-}$ & $0.228 \mathrm{~g}$ \\
\hline 5 & $\mathrm{MgCl}_{2} \cdot 6 \mathrm{H}_{2} \mathrm{O}$ & $0.305 \mathrm{~g}$ \\
\hline 6 & $1 \mathrm{M} \cdot \mathrm{HCl}$ & $40 \mathrm{~mL}$ \\
\hline 7 & $\mathrm{CaCl}_{2}$ & $0.278 \mathrm{~g}$ \\
\hline 8 & $\mathrm{Na}_{2} \mathrm{SO}_{4}$ & $0.071 \mathrm{~g}$ \\
\hline 9 & $\left(\mathrm{CH}_{2} \mathrm{OH}\right)_{3} \mathrm{CNH}_{2}$ & $6.057 \mathrm{~g}$ \\
\hline
\end{tabular}




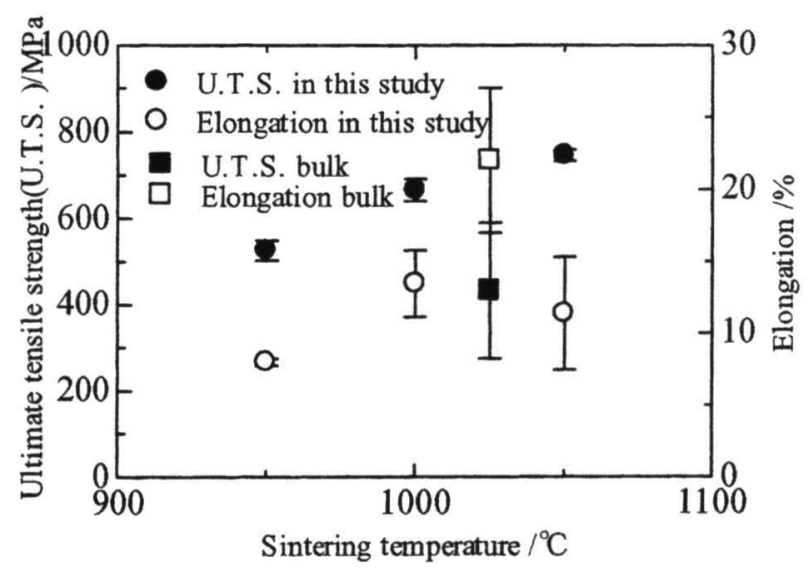

Fig.2 Relationship of U.T.S and Elongation with sintering temperature

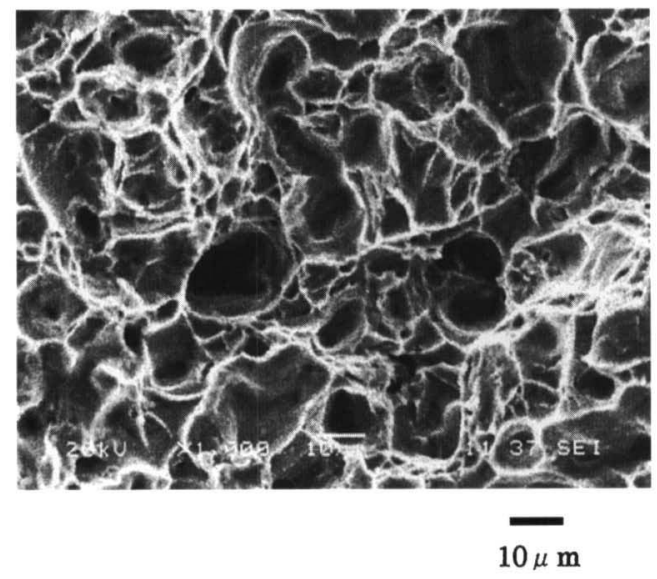

Fig.3 SEM image of fracture surface of sintered $\mathrm{Ti}$

Table 3 Relationship between $\mathrm{pH}$ of the surface-treated $\mathrm{Ti}$ and surface treatment time.

\begin{tabular}{|c|c|}
\hline $\begin{array}{l}\text { Surface-treatment } \\
\text { time s }\end{array}$ & $\begin{array}{l}\mathrm{pH} \text { of surface } \\
\text {-treated Ti }\end{array}$ \\
\hline 0 & $\overline{7}$ \\
\hline 30 & 12 \\
\hline 60 & 14 \\
\hline 180 & 14 \\
\hline
\end{tabular}

生じた. 表面処理した試験片はTable 3に示すように加工時間 60sで pHが14になったことより, 表面処理により生成した強 アルカリ生成物がSBF中のカルシウムイオンやリン酸イオン を析出させる助剤となり疑似骨を生成しやすい環境を作り出 したと考察される.

次に, メカノケミカル反応より生成した生成物の同定を行 うためにXRDの測定を行った. 用いたチタン試験片とHAPの XRDをFig.4に，表面処理後の試験片と生体疑似液に1週間侵 漬後のXRD を Fig.5に示す. 表面処理後のXRDは, チタンと HAPを合成したピークとなった.これは, MIMプロセスで創
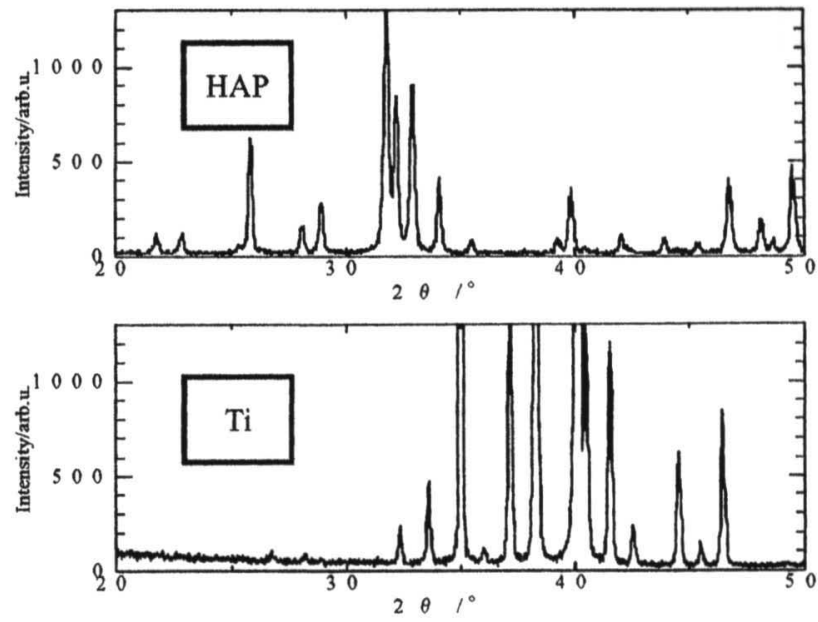

Fig.4 XRD pattern of $\mathrm{Ti}$ and HAP.
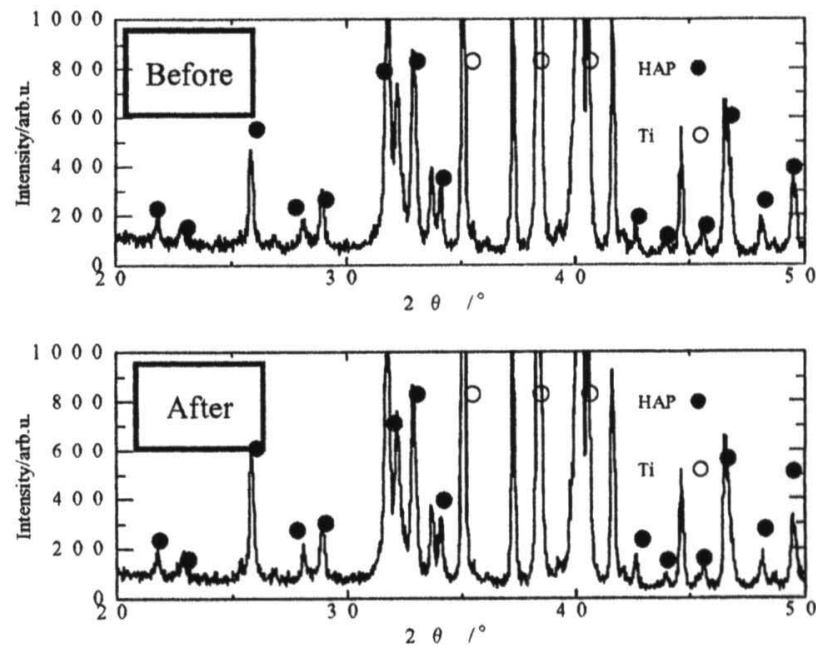

Fig.5 XRD pattern of surface-treated Ti immersed SBF.

製した試験片の表面に凹凸があり, 凹部に未反応のHAP粉が 存在するためHAPのピークが大きくなるため生成物を同定で きないと考察される.また, 疑似体液侵漬後の試験片のXRD は, HAP (002)である $25.7^{\circ}$ のピークが侵漬前より大きくなっ ており，疑似骨が生成したことを示している.さらに，Fig.6 に示すようにEDSの元素分布図より, 表面処理後のチタン試 験片表面に, カルシウム, リン, 酸素が均質に抎散されてお りチタンと HAP 粉が反応した生成物が存在すると予測でき た. Fig.7に表面処理前, 表面処理後, 疑似体液浸漬後のSEM 像を示す．その表面が劇的に変化していることが分かる. Fig.7右上より表面処理後は, 初期に破砕されたHAP燒結体と 研削された表面が観察され, Fig.7左下よりSBFに一週間浸漬 後は, 緻密で均質な骨類似アパタイト層を確認できた.また, Fig.7右下よりその骨類似アパタイト層を20000倍の高倍率で 観察することにより直径約 $100 \mathrm{~nm}$ の球状の結晶が経密に成長 していることが確認された.SBFに一週間浸漬した試験片の EDSによる定性分析を行った結果をFig.8に示す. 骨類似アパ 


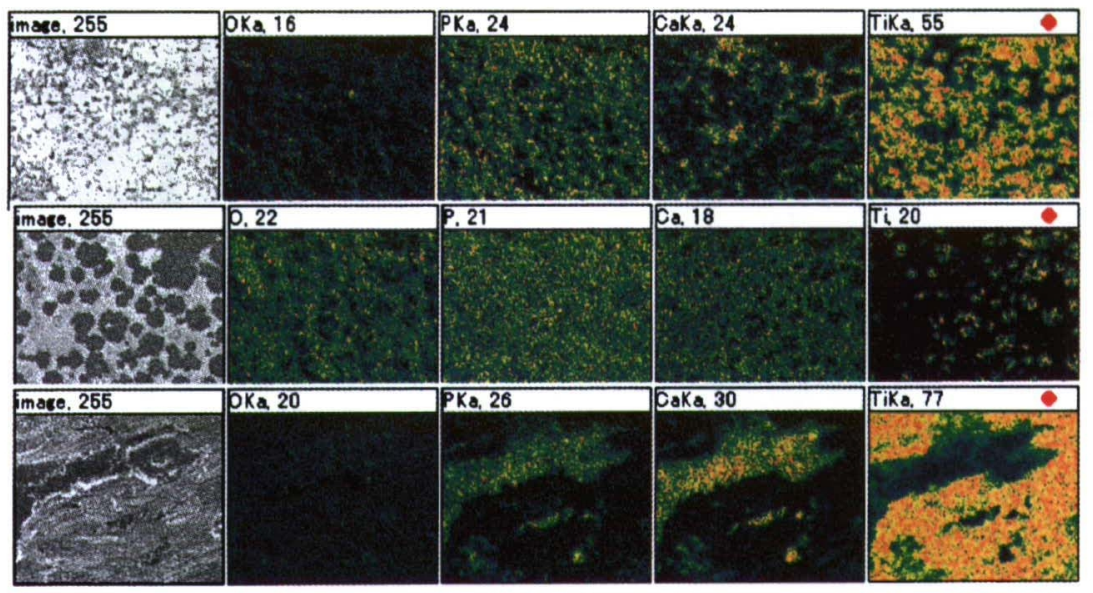

Fig.6 EDX Mapping of the surface-treated Ti.

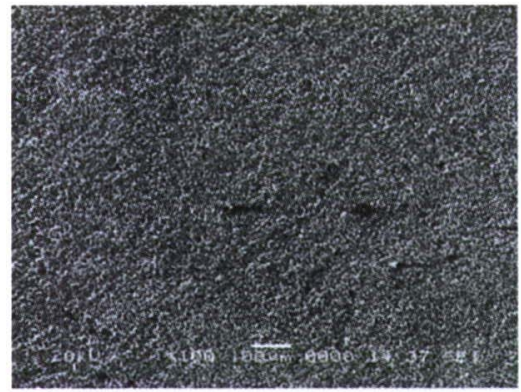

Before surface treatment

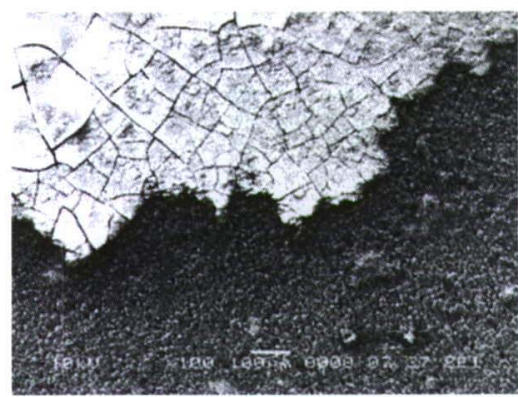

After surface treatment with immersion in SBF for 7 days

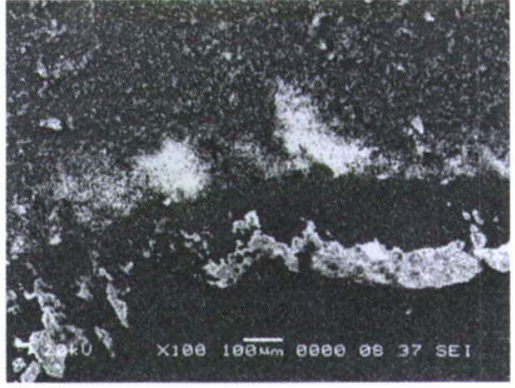

After surface treatment

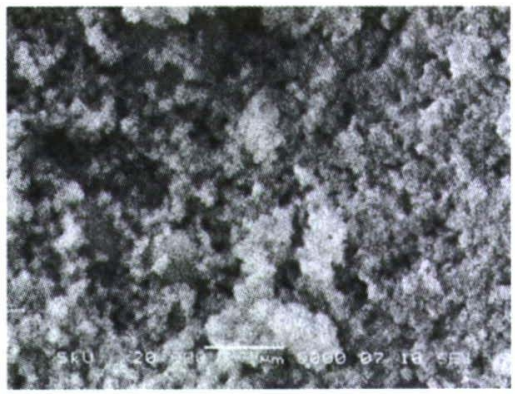

After surface treatment with immersion in SBF for 7 days

Fig.7 SEM micrographs of the Ti before and after the surface treatment.

タイト層からは, カルシウム, リン, 酸素のみ検出され, チ タン未処理表面からは, チタン, カルシウム, リン, 酸素か 検出された. チタン未表面処理からのカルシウム, リン, 酸 素は未反応の凹部に存在する HAP 粉由来のものと考察され, EDSによる定性分析からも表面処理を行った試験片から骨類 似アパタイト層が生成していることが確認された。

\section{4 結 言}

(1) 超臨界脱脂を用いた MIM 法により優れた機械的特性をも
つ純チタン母材に直接 HAP と化学結合する迅速, 簡便な 表面処理を行い, 高い生体活性を付与した人工骨用チタン の創製に成功した.

(2) 表面処理により生成する強アルカリ成分は, SBF中のカル シウムイオンやリン酸イオンを析出させる助㓮となり,加 工面の EDS の元素分布により, チタン, カルシウム, リ ン, 酸素が反応した生成物が疑似骨を成長させる核とな り，骨類似アパタイト層を形成したと考察される.

(3) 本研究で開発したMIMプロセスを応用した生体活性純于 


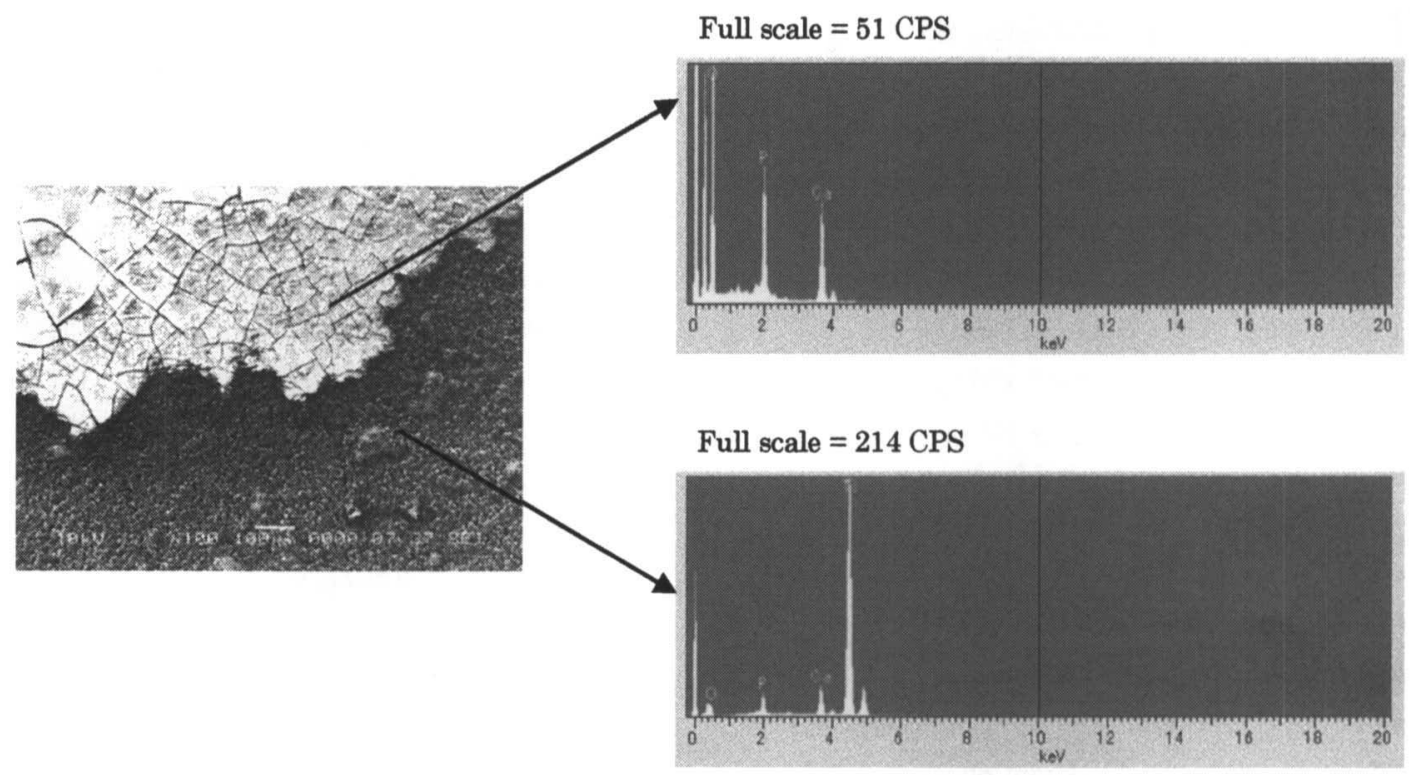

Fig.8 EDX Qualitative analysis of the surface-treated Ti with immersion in SBF for 7 days.

タンを用いて生体,とりわけ歯科材料である人工歯根への 応用が期待される.

\section{文献}

1) M.Semlitsch, H.Weber, R.Streicher and R.Schon: "Joint replacement components made of hot-forged and surface-treated Ti-6Al-7Nb alloy", Biomaterials, 13(1992)781-788.

2) S.A.Brownan and J.E.Lemons: Medical Applications of Titanium and Its Alloys, The material and Biological Issues, Astm In tl, (1990) 76.

3) S.A.Brownan and J.E.Lemons: Medical Applications of Titanium and Its Alloys, The material and Biological Issues, Astm In tl, (1996)88.

4) S.A.Brownan and J.E.Lemons: Medical Applications of Titanium and Its Alloys, The material and Biological Issues, Astm In tl, (1996)96.

5) 岡崎義光, 伊藤喜昌, 伊藤敦夫, 立石哲也: " 生体用 $\mathrm{Ti}$ 合 金の機械的性質に及ぼす合金元素の効果", 日本金属学会 誌, 57(1993)332-337.

6) 岡崎義光, 伊藤喜昌, 立石哲也, 伊藤敦夫: "生体用新 Ti合 金の組織と力学特性に及ほす熱処理の効果", 日本金属学 会誌, 59(1995)108-115.

7) 岡崎義光, 太田学, 伊藤喜昌, 立石哲也: "生体用合金の疑 似体液中での耐食性と不動態皮膜中の合金元素の役割 ", 日本金属学会誌, 59(1995)229-236.

8) 岡崎義光, 許健司, 伊藤喜昌, 立石哲也: "Vを含まない生 体用 Ti合金の耐食性に及ぼすMo と Pdの効果", 日本金属 学会誌, 59(1995)1061-1069.

9) 岡崎義光, 許健司, 伊藤喜昌, 立石哲也: "遠心鋳造した生
体用新 $\mathrm{Ti}$ 合金の耐食性と室温強度 ", 日本金属学会誌, 59 (1995)1070-1077.

10) S.A.Brownan and J.E.Lemons: Medical Applications of Titanium and Its Alloys, The material and Biological Issues, Astm In tl, 45(1996)138.

11) Y.Okazaki, Y.Ito, K.Kyo and T.Tateishi: "Corrosion resistance and corrosion fatigue strength of new titanium alloys for medical implants without $\mathrm{V}$ and $\mathrm{Al}$ ", Materials Science \& Engineering A, 213(1996)138-147.

12) F.H.Froes and I.Caplan: Titanium Science and Technology, TMS, (1993) 2705.

13) F.H.Froes and I.Caplan: Titanium Science and Technology, TMS, (1993) 2697.

14) M.Niinomi: "Mechanical properties of biomedical titanium alloys", Mat. Sci. Eng., A243(1998)231-236.

15) P.A.Blenkinsop, W.J.Evans and H.M.Flower: Science and Technology, The Inst. Materials (London), (1996)1760.

16) D.Kuroda, M.Niinomi, M.Morinaga, Y.Kato and T.Yashiro: "Design and mechanical properties of new $\beta$ titanium alloys for implant materials", Mat. Sci. Eng., A243(1998)244-249.

17) S.A.Brown and J.E Lemon: Medical Application of Titanium and Its Alloys, Material and Biological Issues, Astm In tl, (1996)3.

18) 新家光雄, 渡部昇, 北出真, 福井壽男, 長谷川二朗: " 緻密 骨の破壊特性におよぼすミクロ構造の影響", 日本機械学 会論文集 A, 64(1998)312-318.

19) S.A.Brown and J.E.Lemons: Medical Applications of Titanium and Its Alloys, Astm In tl, (1996)60.

20) R.M.German: 粉体治金の科学, 三浦秀士, 高木研一郎訳, 内 田老鶴固 , (1996). 
21）清水透，北島明子，岡田智史，淵澤定克，増井孝実: "MIM プロセスを用いたチタン材料の機械的特性の改善 ", 粉体 粉末治金協会講演概要集平成14年度秋季大会, (2002) 108.

22) T.Yamamuro, L.L.Hench and J.Wilson: Handbook of Bioactive Ceramics, Vol.II, CRC Press, Boca Raton, (1990)133-142.

23) J.E.Hulburt and S.F.Hulburt, Rose-Hulman: Biocerzmics, Vol.3, Institute of Technology, Terre Haute, (1993)199-212.

24) P.Ducheyne, S.Radin, M.Heughebaert and J.C.Geughebaert: "Calcium phosphate ceramic coatings on porous titanium: effect of structure and composition on elecrtophoretic deposition, vacuum sintering and in vitro dissolution", Biomatrials, 11 (1990)244-254.

25) H.Hero, H.Wie, R.B.Jorgensan and I.E.Ruyter: "Hydroxyapatite coating on Ti produced by hot isoststic pressing", J. Biomed. Mater. Res., 28(1994)343-348.

26) M.Shirkhanzardeh: "Bioactive calcium phosphate coatings prepared by electrodeposition", J. Mater. Sci. Lett., 10(1991) 1415-1417.

27) H.Ishizawa and M.Ogino: "Formation and characterization of anodic titanium oxide films containing $\mathrm{Ca}$ and $\mathrm{P} ", \mathrm{~J}$. Biomed. Mater. Res., 29(1995)65-72.

28) K.Yamashita, T.Arashi, K.Kitagaki, S.Yamada, T.Uegaki and K. Ogawa: "Preparation of Apatite Thin Film through rfSputtering from Calcium phosphate Glasses", J. Am. Ceram. Soc., 77(1994)2401-2407.

29) J.Li, Ong and L.C.Lucas: "Post-deposition heat treatment for ion beam sputter deposited calcium phosphate coatings", Biomaterials, 15(1994)337-341.

30) 小久保正, 金銥敏: "生体内で自然にアパ夕イト被膜を形 成し，骨と結合する金属 ", Mater. Integ., 12(1999)39-45.

31) P.Vincenzini, Techna SL, Faenza T.Nakamura and S.Nishiguchi: "Bioactive titanium and its alloys", In Sci, (1999)289-300.

32) 小久保正, 金鎔敏: "バイオミメティックス法: 常温常圧 でのセラミックス調整", セラミックス, 34(1999)368-372.

33) 小久保正, 川下将一: "病を瘾すセラミックス - 現状と展 望 ", セラミックス, 34(1999)507-515.

34) T.Kokubo: "Novel inorganic materials for biomedical applications", in Proc. of the Sixth Japan Inter. SAMPE Symp. Vol. 1, Tanimoto and T.Morii, Japan Chapter of SAMPE Tokyo,
(1999)1-6

35）小久保正, 金鉉敏: "生体活性材料設計のための表面構造 制御 ", 表面科学, 20(1999)621-628.

36) H.-M.Kim, F.Miyaji, T.Kokubo, S.Nishiguchi and T.Nakamura: "Bonelike apatite formation on porous titanium metal subjected to $\mathrm{NaOH}$ and heat treatments", in Bioceramics Vol. 12, ed. by H.Ohgushi, G.W.Hastings and T.Yoshikawa, World Sci., Singapore, (1999)117-120.

37) S.Nishiguchi, T.Nakamura, H.Kato, H.Fujita, M.Oka, H.M.Kim, F.Miyaji and T.Kokubo: "Bone-bonding behavior of porous titanium implant after alkali and heat treatment", in Bioceramics Vol.12, ed. by H.Ohgushi, G.W.Hastings and T.Yoshikawa, World Sci., Singapore, (1999)299-302.

38) S.Nishiguchi, T.Nakamura, M.Kobayashi, H.Kato, H.-M.Kim, F.Miyaji and T.Kokubo: "The effect of heat treatment on bonebonding ability of alkali-treated titanium", Biomaterials, 20 (1999) 491-500.

39) S.Nishiguchi, T.Nakamura, M.Kobayashi, H.Kato, H.-M.Kim, F.Miyaji and T.Kokubo: "Enhancement of bone-bonding strength of titanium alloy implants by alkali and heat treatments", J. Biomed. Mater. Res. (Appl. Biomater.), 48(1999)689-696.

40) 末次恒夫他編: 歯科インプラント, 厚徳社, (2000)299-304.

41）金鉝敏,宮路史明，小久保正, 西口滋, 中村孝志: "化学処 理した多孔性チタン金属表面での骨類似アパタイト形成", Orthop. Ceram. Imp., 18(2000)15-18.

42) 小久保正, 金鉝敏: "化成処理, 高温処理: 人工骨, 人工関 節 ", 表面技術, 51(2000)54-56.

43) T.Kokubo, H.-M.Kim, H.Takadama, T.Miyazaki and T.Nakamura: "Apatite forming mechanism on amorphous phases in body environment", in Ceram. Trans, Vol. 101, ed. by D.E.Clark, D.C.Folz and J.H.Simmons, Am. Ceram. Soc., Ohio, (2000)167-176.

44) 北島明子,清水透,依田智,增井孝実: "超臨界二酸化炭素 に溶解度を有する分散剤を用いたMIMプロセズ,粉体お よび粉末治金, 49(2001)522-526.

45) T.Kokubo, H.Kushitani, S.Sakka, T.Kitsugi and T.Yamamuro, "Solutions able to reproduce in vivo surfacestructure changes in bioactive glass-ceramic A-W", J. Biomed. Meter. Res., 24 (1990)721-734. 